\title{
PUBLISHER CORRECTION OPEN Publisher Correction: Rabies-based vaccine induces potent immune responses against Nipah virus
}

Rohan Keshwara ${ }^{1}$, Thomas Shiels ${ }^{1}$, Elena Postnikova ${ }^{2}$, Drishya Kurup ${ }^{1}$, Christoph Wirblich ${ }^{1}$, Reed F. Johnson ${ }^{3}$ and Matthias J. Schnell ${ }^{1,4}$

npj Vaccines (2019)4:18; https://doi.org/10.1038/s41541-019-0112-x

Correction to: npj Vaccines https://doi.org/10.1038/s41541-0190109-5, Published online 15 April 2019

In the original published version of this Article, the figure legends were attached to the wrong figures. The legend for Fig. 2 was moved to Fig. 4, the legend for Fig. 3 was moved to Fig. 2, and the legend for Fig. 4 was moved to Fig. 3. The PDF and HTML versions of the Article have been corrected. Attribution 4.0 International License, which permits use, sharing, adaptation, distribution and reproduction in any medium or format, as long as you give appropriate credit to the original author(s) and the source, provide a link to the Creative Commons license, and indicate if changes were made. The images or other third party material in this article are included in the article's Creative Commons license, unless indicated otherwise in a credit line to the material. If material is not included in the article's Creative Commons license and your intended use is not permitted by statutory regulation or exceeds the permitted use, you will need to obtain permission directly from the copyright holder. To view a copy of this license, visit http://creativecommons. org/licenses/by/4.0/.

(c) The Author(s) 2019

\footnotetext{
${ }^{1}$ Department of Microbiology and Immunology, Sidney Kimmel Medical College at Thomas Jefferson University, Philadelphia, PA 19107, USA; ${ }^{2}$ Integrated Research Facility, National Institute of Allergy and Infectious Diseases, National Institutes of Health, Fort Detrick, MD 21702, USA; ${ }^{3}$ Emerging Viral Pathogens Section, National Institute of Allergy and Infectious Diseases, National Institutes of Health, Bethesda, MD 20892, USA and ${ }^{4}$ Jefferson Vaccine Center, Sidney Kimmel Medical College at Thomas Jefferson University, Philadelphia, PA 19107, USA
}

Correspondence: Matthias J. Schnell (Matthias.Schnell@jefferson.edu)

These authors contributed equally: Rohan Keshwara, Thomas Shiels

Published online: 13 May 2019 